\title{
THE SUSPENDED MATTER IN SEA WATER AND ITS SEASONAL CHANGES AS AFFECTING THE VISUAL RANGE OF THE SECCHI DISC
}

\author{
By W. R. G. Atkins, F.R.S., Pamela G. Jenkins \\ and F. J. Warren \\ The Plymouth Laboratory
}

(Text-figs. I and 2)

In a previous paper (Armstrong \& Atkins, I950), 201 . samples from International Hydrographic Station England No. I (E I), about Io miles south-west of the Eddystone in the English Channel, were filtered through collodion membranes of $\mathrm{I} \cdot 09 \mu$ average pore diameter (A.P.D.).

Between June 1948 and November 1949 the residue from these surface samples, when dried and ignited, amounted to $0 \cdot 45^{-2} \cdot 77 \mathrm{~g} / \mathrm{m}^{3}$ (or parts per million). These deposits consisted of $55-17 \%$ silica, $28-3 \%$ ferric oxide, 20 to under I $\%$ of alumina, and 70 (or, excluding one high value, 29) to $9 \%$ calcium carbonate. A few determinations of insoluble organic matter gave to I. I5I. 77 p.p.m. when dried at $100^{\circ} \mathrm{C}$. Pettersson (1934b), using the glass filters of Schott (Jena), found I·4 p.p.m. for the total organic and inorganic matter similarly dried, from surface water in the Gullmar Fjord during the spring outburst.

The suspended matter, organic, and inorganic, is responsible for by far the greater part of the scattering of light (Atkins \& Poole, I952), the extinction of which is due to absorption by the water and suspended matter and to scattering.

The difference in the optical properties of water samples depends upon the amount and properties of the suspended matter and the 'yellow substance', which is supposed to be in solution. Furthermore, as the scattering produced by very fine particles affects the short wave end of the spectrum more than the rest of it, it acts in a manner similar to a yellow filter, and as far as we know 'yellow substance' has never been isolated. In the red and the deep red the much increased absorption reduces the relative importance of the scattered light.

\section{The Comparison of Suspended Matter on Filter Discs}

As shown by Atkins \& Jenkins (I953) a good comparison can be made visually and in photographs; it is easy to place the discs in order of increasing deposit, when I 1. or 21 . of water are passed through a collodion membrane. Ordinarily the discs are of a greyish mud colour, tinged sometimes with faint yellowish 
green. On 2I October 1952, and on 25 March 1953, the deposit was a light buff darkening with quantity to chocolate. This happened again on 5 October 1953.

The discs were photographed to get a permanent record. This places them in relative order for each series, but it is well known to be very difficult to get an accurate measurement of intensity of grey from a photograph.

Accordingly we determined the diffuse reflexion relative to that of an unused disc, namely the relative albedo. For comparison we also determined this in the photograph for 2I January 1953, taking the white filter-paper background as I0o. Actually its reflexion may be higher or lower than that of the filter disc, but, as shown in the print reproduced in Fig. I, the two were in some places indistinguishable, or in others the filter disc was very slightly the lighter. The effect would be to give a relative albedo $\mathrm{I} \%$ or $2 \%$ too high.

The relative albedo was found as follows. A selenium rectifier cell was mounted in the place of an eye-piece on an old microscope stand, on the stage of which the sample discs were placed inside a ring immediately beneath the tube, which was devoid of lenses. The discs were illuminated using a $36 \mathrm{~W}$ I2 $\mathrm{V}$ car headlight, at about $45^{\circ}$ angle of incidence. The cell was racked up till its field of view embraced the greater part of the disc. With this arrangement a dry collodion disc gave I60-200 scale divisions when the cell was connected to a galvanometer of sensitivity $0.946 \times \mathrm{IO}^{-9} \mathrm{~A} / \mathrm{mm}$ and resistance $686 \Omega$. Even with such a high resistance the selenium cell showed a rectilinear relation between current and light for such small currents, under $0 \cdot 2 \mu \mathrm{A}$. It was found that, with the depths of tint given on the discs by 21 . of water from station E I, the relation between quantity of suspended matter and tint was rectilinear. Thus the line for a sample as obtained and when diluted with distilled water was rectilinear for $75,50,25,20,15,10,5 \%$ sea water plotted against the albedo. The inorganic suspended matter was thus studied along with the phytoplankton.

It had been shown by Atkins \& Poole (1952) that the scattering of light by surface samples of sea water was usually greater than that by the deeper water. To ascertain the variation with depth of the residue of the suspended matter, after extraction with $80 \%$ aqueous acetone to remove chlorophyll and carotenoids, the discs were ignited and weighed. The samples were taken at Station EI, I9 June 1952. The photograph of these discs before extraction is shown in Atkins \& Jenkins (1953). The ignited residue was $\mathrm{I} \cdot 6 \mathrm{~g} / \mathrm{m}^{3}$ for surface water; $\mathrm{r} \cdot 0$ for 5 and $10 \mathrm{~m}$, and $0.4 \mathrm{~g} / \mathrm{m}^{3}$ for $\mathrm{I} 5,20,25$ and $50 \mathrm{~m}$. It is clear that an estimate based upon surface samples only may be much too high. The change in amount of residue did not coincide with the thermocline. The aqueous acetone extraction probably left some sea salt behind, but its major constituent, sodium chloride, would have been volatilized during the ignition, so it is unlikely that sea salt introduced an error. Under the microscope the residue appeared to be mostly amorphous, but with numerous crystalline mineral particles. 
Taking the above values for mineral suspended matter and interpolating suitably, the $0-20 \mathrm{~m}$ column for I9 June was found to contain $18.0 \mathrm{~g}$, which may be taken as having sp.gr. $2 \cdot 8$, and so a volume $6 \cdot 4 \mathrm{~cm} .{ }^{3}$ If the suspended matter consisted of little cubes of I $\mu$ sides, a limit that might not pass the collodion filter, there would be $6.4 \times 10^{12}$ of them in a $20 \mathrm{~m}^{3}$ column, a depth at which one might see a Secchi disc in clear water. The number given is equivalent to having 32 in a haemocytometer field, $\mathrm{I} \mathrm{mm}^{2}$ in area and O.I mm deep. Of this area the cubes would obstruct $32 \mu^{2}$, out of the total IO ${ }^{6} \mu^{2}$. Thus were the cubes entirely opaque and-quite impossible of coursearranged so as not to overlap-one would have a complete screen cutting off all light in $3.12 \mathrm{~m}$. It so happened that on this date, I9 June I952, the Secchi disc could be seen to $23 \mathrm{~m}$, the maximum for the years 1948 to I953 inclusive. The date also gave a minimum for the chlorophyll for that summer, and with the assumptions made in the earlier paper the $37 \mathrm{mg}$ of chlorophyll found in the $20 \mathrm{~m}$ column would indicate $6.4 \mathrm{~g}$ for the wet weight of the phytoplankton. Obviously this would give the same number of $\mathrm{I} \mu^{3}$ organisms as there were mineral particles, and the size is a possible one. These, however, would be nearly transparent and the mineral particles would have a higher refractive index and would produce a greater effect optically. The coincidence in the numbers of particles is quite fortuitous, and occurred when the phytoplankton was at a minimum.

It is obvious that if the particles (or organisms) had sides $2 \mu$ in length, the volume would have been $8 \mu^{3}$ with $0.8 \times \mathrm{IO}^{12}$ particles in a $20 \mathrm{~m}$ column, and only four, with area $16 \mu^{2}$, in the volume of the haemocytometer field. Thus as the size increases the scattering and obscuration occasioned by the same mass of particles is much reduced. It follows that the optical effects produced by equal numbers of different species of the phytoplankton may be very different.

\section{Microscopic Examination of the Suspended Matter}

Dr A. G. Lowndes kindly examined some of the filter discs, which were handed to him after the plant pigments had been removed by $80 \%$ aqueous acetone in the cold. They were examined first of all by means of strong reflected light under a low-power binocular microscope, magnification 20 diameters, and presented a ground mass of varying colour which could not be resolved even under much higher powers. The ground mass appeared to be a fine mud or clay. A number of black specks and fibres were also present. These were removed, mounted in Canada balsam and observed with crossed nicols. The fibres were from wood and the remains of rope or twine. The wood fibres consisted of both oak and pine or woods closely allied to them. The other fibres consisted of such things as manila and coir and possibly a little jute. The black or dark specks consisted of carbonaceous matter, probably to be associated with soot, pitch or tar. These were readily volatilized when heated on the corner of the slide over a bunsen. Other dark specks consisted of oxides 
of iron, possibly from the stokeholds of ships. Fragments of shell were always present. There was very little actual mineral matter, other than the clay, except for an occasional grain of quartz or cordierite one of which was about O.I $\mathrm{mm}$ in diameter. There was also a small amount of kaolinite. There were occasional sponge spicules, also diatoms and copepods.

Some incinerated residue from the discs of 19 June was also examined. This consisted of the minerals quartz and cordierite, also some micaceous matter, probably sericite. Broken grains of felspar (orthoclase) were also present, as well as a small fragment of tourmaline. Most of these grains were under $40 \mu$ in diameter. Dark grains of iron oxides were fairly abundant.

Cordierite (syn. iolite) may be found in minute crystals in granite and is not very common. It is a silicate of the oxides of aluminium, magnesium and iron. Orthoclase felspar is typically a silicate of aluminium and potassium and is common in granite in Cornwall and in most granites everywhere. Tourmaline also is common in granite and varies in composition, it usually consists of silicates of aluminium, sodium and boron.

\section{The Variation in Suspended Matter Throughout the Year}

The greater part of the organic suspended matter arises from the phytoplankton and a quantitative study of this, based upon the chlorophyll extracted from the filter discs, was made for I 95 I- 52 by Atkins \& Jenkins (I953). ${ }^{1}$ But the collodion discs do not appear to alter greatly in depth of colour when extracted with $80 \%$ acetone, so it seems that the greater part of the residue, organic and inorganic, remains on them. From June 1952 to January 1953 photographs of the discs were obtained. Those for June and July 1952 have already been published and may be compared with Fig. I which shows the discs for 22 September 1952 and 2I January 1953. In September the surface disc is the darkest, and Table I shows that this is quite usual, but it is not usual to have the other discs so like the surface; from 15 to $50 \mathrm{~m}$ the water seemed uniform, with 5 and $10 \mathrm{~m}$ slightly poorer in suspended matter. This uniformity is the result of the vertical mixing of the water, the whole column having just reached the isothermal state. Such a column is less stable than one with an upper warm layer, but in spite of this and the fact that the water had cooled from $\mathrm{I} 4.24$ to $\mathrm{I} 2.3 \mathrm{I}^{\circ} \mathrm{C}$ in the 8 weeks' interval, the November column gave a very dark surface disc, and, after some mixing in December, so did that of January, as shown in Fig. I. With very little plankton at this season, the effect must be almost entirely due to lifeless matter, much of which rapidly re-accumulates near the surface. It is not known how thick this layer is, but it is remarkable that photoelectric measurements of submarine light intensity have often shown a surface loss for which a satisfactory explanation has been

\footnotetext{
${ }^{1}$ In this paper the following corrigenda should be noted. At the bottom of p. 50I and top of p. 502, 'g.' (in three places) should read 'kg'. In the Summary (6th and 7 th lines) 'wet weight of phytoplankton' should read 'chlorophyll'.
} 


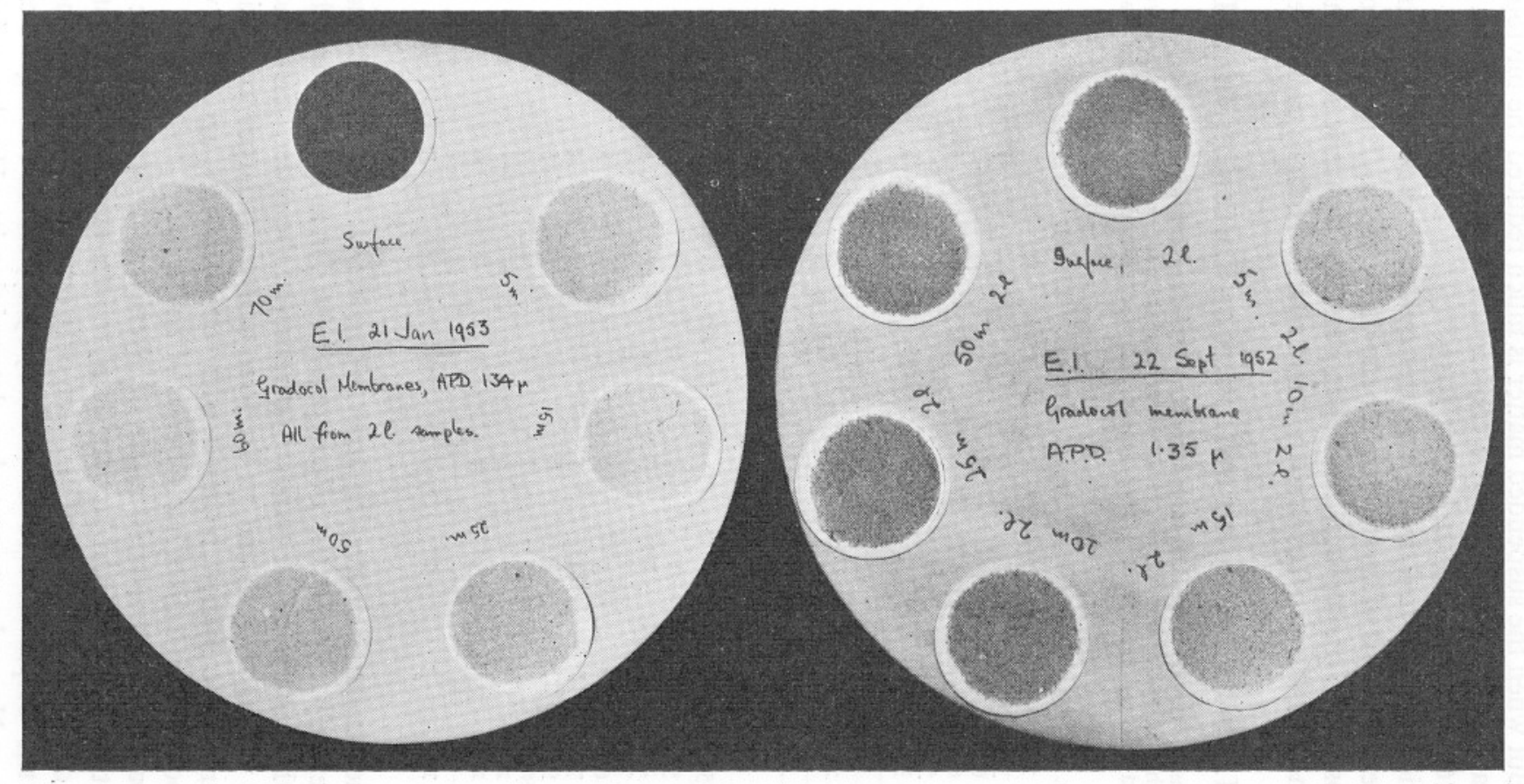

Fig. I. Gradocol membranes after filtering 21. of water from Station E I September 1952 and January 1953. 
difficult. But when the suspended matter is much reduced the phytoplankton portion may cause a maximum at a considerable depth, $25 \mathrm{~m}$, as on I 5 July 1952, on I6 March and on Io August 1953.

As previously explained, in order to get quantitative results, recourse was had to determinations of the relative albedo of the discs. Table II shows that the albedos of the photograph tend to increase the contrast somewhat. But the agreement of the visual examination and albedo methods can be very good

\section{Table I. Order of Amount of Deposit on Collodion Filter Discs}

The depths are placed in ordinal rank according to the amount of deposit on the collodion filter discs, the darkest colour ranking first, from June 1952 to November I953. Two litres of water filtered through each from depths shown, at International Hydrographic Station, E I.

\begin{tabular}{|c|c|c|c|c|c|c|c|c|c|}
\hline $\begin{array}{l}\text { Depth } \\
\text { (m) }\end{array}$ & I9. vi. & I5. vii. & 20. viii. & 22. ix. & 20. xi. & 22. xii. & 2I. i. & 24. ii. & I6. iii. \\
\hline 0 & I & 2 & I & I & I & I & I & I & 2 \\
\hline 5 & 3 & 4 & 4 & 7 & 6 & 4 & 5 & 3 & 6 \\
\hline Io & 6 & 7 & 5 & 6 & - & - & - & - & 4 \\
\hline I5 & 6 & 4 & I & 2 & 2 & 4 & 6 & 2 & 2 \\
\hline 20 & 5 & 4 & 3 & 2 & - & - & - & - & 4 \\
\hline 25 & 3 & I & 5 & 2 & 6 & 4 & 2 & 3 & I \\
\hline 30 & - & - & - & - & - & - & - & - & 9 \\
\hline 40 & - & - & - & - & - & - & - & - & - \\
\hline 50 & 2 & 2 & 5 & 2 & 2 & 2 & 2 & 3 & 8 \\
\hline 60 & - & - & - & - & - & 4 & 6 & - & - \\
\hline 70 & - & - & - & - & - & 2 & 2 & - & 7 \\
\hline Depth & & & & & & & & & \\
\hline$(\mathrm{m})$ & 25. iii. & 27. iv. & 22. vi. & 20. vii. & Io. viii. & 8. ix. & 5. x. & 20. x. & I7. xi. \\
\hline 0 & 5 & I & I & 7 & 5 & 7 & 2 & I & I \\
\hline 5 & 2 & 5 & 2 & 2 & 5 & I & 9 & 2 & 2 \\
\hline Io & 7 & - & - & - & 4 & 3 & I & 6 & 4 \\
\hline I5 & 6 & 5 & 5 & 7 & 8 & 5 & 8 & 3 & 3 \\
\hline 20 & 7 & 8 & 4 & 5 & 2 & 6 & 4 & 5 & 5 \\
\hline 25 & 9 & 8 & 3 & 6 & I & 9 & 5 & 4 & 5 \\
\hline 30 & Io & 5 & 5 & 7 & 3 & 4 & 7 & 7 & 9 \\
\hline 40 & 2 & 2 & - & 4 & - & - & - & - & - \\
\hline 50 & 2 & 3 & 5 & 2 & 8 & 2 & 6 & 7 & 7 \\
\hline 70 & $I$ & 3 & 5 & I & 7 & 8 & 3 & 7 & 8 \\
\hline
\end{tabular}

as far as the placing in decreasing order is concerned. Thus for I6 March the two agree exactly save that the albedo places the $5 \mathrm{~m}$ as seventh and the $70 \mathrm{~m}$ as sixth, whereas the visual comparison reversed the order. Here, however, the albedo was 74 for $5 \mathrm{~m}$ and 73 for $70 \mathrm{~m}$ and errors larger than this could easily occur. On Io August, however, with very pale discs, agreement was not at all as good, but five discs had albedos of $82-84 \%$.

Going back to the re-establishment of layering as indicated by the photographs for the November and January discs, there is evidence of long standing that this is due to the presence of plankton or to organic matter. It is shown by a study of the 'respirable carbon' (Atkins, 1922), for on storing water taken from E $\mathrm{I}$ on 9 November I92I and re-determining its $\mathrm{pH}$ value at intervals, 
it was seen that the production of carbon dioxide was markedly greater between 20 and $25 \mathrm{~m}$ than elsewhere, with a minor peak in the graph at $5 \mathrm{~m}$ as seen in the I92I figure.

\section{Table II. Relative Albedo of Collodion Discs During 1953}

The discs had filtered 21 . of sea water taken at various depths from Station E I during I953. The second column shows the relative albedo of the photographic print of the January series, alongside of the direct test on the disc as in column 3 .

\begin{tabular}{|c|c|c|c|c|c|c|c|c|c|c|c|c|}
\hline $\begin{array}{c}\text { Depth } \\
\text { (m) }\end{array}$ & 2I. i. & 2I. i. & 23. ii. & I6. iii. & 25. iii.* & 27. iv. & 22. vi. $\dagger$ & Io. viii. & 8. ix. & 5. x.* & 20. $x$. & I7. xi. \\
\hline 0 & 29 & 25 & 64 & 66 & 73 & 55 & 37 & 84 & 73 & 49 & 60 & 58 \\
\hline 5 & 88 & 68 & $8 \mathrm{I}$ & 74 & 64 & 66 & 49 & 83 & 54 & $6 \mathrm{I}$ & 64 & 64 \\
\hline IO & - & - & - & $7 \mathrm{I}$ & $8 \mathrm{I}$ & - & - & 84 & $6 \mathrm{I}$ & $4 \mathrm{I}$ & 76 & 62 \\
\hline I5 & 95 & $8 \mathrm{I}$ & 73 & 66 & 78 & 67 & 55 & 94 & 67 & 59 & 70 & 62 \\
\hline 20 & - & 一 & & $7 \mathrm{I}$ & 82 & 74 & 52 & 82 & 70 & 59 & 72 & 70 \\
\hline 25 & 75 & 57 & 82 & $6 \mathrm{I}$ & 86 & 74 & 50 & 66 & 79 & 57 & 72 & 70 \\
\hline 30 & - & - & - & 82 & 88 & 66 & 54 & 89 & 69 & 54 & 79 & 80 \\
\hline 40 & - & - & - & - & 72 & $6 I$ & -1 & - & - & - & - & - \\
\hline 50 & 75 & 63 & 82 & 75 & 70 & 63 & 55 & 74 & 68 & 55 & $8 \mathrm{I}$ & 73 \\
\hline 60 & 95 & $8 I$ & 一 & - & $\overline{66}$ & $\overline{6}$ & & & $\overline{70}$ & & $\overline{8 a}$ & \\
\hline 70 & 88 & 62 & 一 & - & 66 & 64 & 55 & 82 & 73 & 55 & 82 & 79 \\
\hline
\end{tabular}

\section{Visual Range of the Secchi Disc in Relation to the Phytoplankton}

It is known that the visual range of an object is affected by the illumination received by the intervening medium, air or water, as with strong illumination more light is scattered in the line of sight. We are indebted to $\mathrm{Dr} \mathrm{H}$. H. Poole for pointing out that determinations of visual range, when the line of sight is shaded from sunlight by the hull of a ship, are of necessity higher than when not thus shaded. However, the shading of the range is here not from direct sunlight, as in air, but from sunlight much reduced in intensity by passage through the water and with some surface loss. There is, on the other hand, a large reduction in visual range when the sunlit surface of the sea is interposed between the eye and the object. It seems preferable, therefore, to accept readings of the range made through a shaded water surface.

Thus on I2 April 1948, the sky was cloudless and the sea surface glassy; the disc was seen to $17 \mathrm{~m}$ in the sun, but to $2 \mathrm{I} \mathrm{m}$ in the shade. Under the same conditions on Io May the depths were, respectively 19 and $22 \mathrm{~m}$. In more opaque water at the same station, E I, the sun and shade readings were 6.5 and $7.7 \mathrm{~m}$. Care was taken to have several youthful observers. It is obviously more difficult to see this small disc when the water is rough, but with patience consistent readings can be got. The colour seen here is greenish for $9 \mathrm{~m}$ and a lovely blue for $2 \mathrm{Im}$.

The visual range of the Secchi disc has been determined for many years. The results using a $20 \mathrm{~cm}$ disc at Station E I from I948 to I953 are shown in Table III. 
Table III. Visual Range of 20 cm Secchi Disc at Station E I

$\mathrm{D}$, date; $\mathrm{M}$, range in metres. Observations in shadow of ship.

\begin{tabular}{|c|c|c|c|c|c|c|c|c|c|c|c|c|}
\hline & & 48 & & 49 & I9 & & & 51 & & 52 & & 53 \\
\hline & D & M & D & M & D & M & D & M & D & M & D & M \\
\hline Jan. & - & - & - & - & I8 & II & 24 & $I I$ & 7 & 12 & $2 \mathrm{I}$ & 16 \\
\hline Feb. & 2 & 8 & - & - & - & - & 26 & 13 & 5 & 14.5 & 23 & I5 \\
\hline Mar. & 3 & I6 & I & 18 & - & - & $\overline{0}$ & - & I I & $I 2$ & I6 & 13 \\
\hline Mar. & Io & $17 \cdot 5$ & - & - & 24 & 13 & 28 & IO & - & 一 & 25 & I6 \\
\hline Apr. & I2 & $2 I$ & I3 & 13 & - & - & - & - & I6 & $I_{3}$ & I3 & 14 \\
\hline Apr. & - & - & - & - & - & 二 & 25 & 14 & $\bar{x}$ & - & 27 & $I I$ \\
\hline May & I0 & 22 & 9 & 14.5 & 3 & I3 & I7 & $20 \cdot 5$ & I5 & 9 & II & $7 \cdot 5$ \\
\hline June & 9 & 9 & 6 & 19.5 & - & - & - & 一 & - & - & 8 & 22 \\
\hline June & I5 & IO & - & - & 一 & - & - & - & I9 & 23 & 22 & $I I$ \\
\hline July & - & - & 4 & $2 I$ & I9 & I5 & I7 & 22 & I5 & 18 & 20 & $I I$ \\
\hline July & $\bar{\sigma}$ & - & 8 & 16 & $\overline{-}$ & $\bar{x}$ & $\overline{7}$ & - & 二 & $\bar{x}$ & - & $\overline{-}$ \\
\hline Aug. & I6 & $7 \cdot 5$ & I7 & 18 & 23 & I4 & 22 & I4 & 20 & $I I$ & IO & 17 \\
\hline Aug. & - & - & 29 & 17 & $\overline{20}$ & $\overline{I 3}$ & $\overline{27}$ & $\overline{0}$ & $\overline{20}$ & $\overline{58}$ & $\overline{8}$ & $\overline{I T}$ \\
\hline $\begin{array}{l}\text { Sept. } \\
\text { Oct. }\end{array}$ & 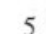 & I2 & $\overline{6}$ & $\overline{I I}$ & 23 & $\begin{array}{l}13 \\
14\end{array}$ & 24 & $\begin{array}{r}9 \\
18\end{array}$ & $2 \mathrm{I}$ & 10 & $\begin{array}{l}0 \\
5\end{array}$ & $\begin{array}{l}I I \\
I^{\star}\end{array}$ \\
\hline Oct. & - & - & - & - & - & - & - & - & 21 & 13 & 20 & 18 \\
\hline Nov. & 一 & - & 8 & 9 & 22 & I I & 27 & I3 & 20 & 14.5 & I7 & I7 \\
\hline ec. & - & - & - & - & - & - & - & - & 22 & 14 & I4 & I6 \\
\hline
\end{tabular}

Depths are shown in italic, save maxima, in bold, and minima, in roman type.

* $\mathrm{I}$ m added to correct for observation having been made in weak sunshine.

Several workers have presented results for phytoplankton and visual range of the Secchi disc which indicate an inverse relation between the two sets of results. Thus during the Great Barrier Reef expedition Marshall(I933) showed the $20 \mathrm{~cm}$ disc depths and number of diatoms per litre. The figures relate to hauls with the fine silk tow-net and wind action on the shallow water was a serious disturbing factor. Nevertheless, in her I-year curve seven marked decreases in the disc readings coincided with high diatom numbers.

During the same expedition Russell \& Colman (1934) found that the curve for total copepods taken in oblique hauls of the silk net follows closely that for the depth at which the disc disappeared. The peaks in the plankton curve occurred when the water was clearest. They considered that this was due to the copepods, etc., having moved down when the light passing through very clear water became too bright. This seems very probable, but the absence of the animals may in itself have contributed to the clearness, though the larger the animal is, the less is its obscuring effect over a large area, since finely divided matter has a greater surface, weight for weight.

Pettersson, too (I934a), cited phytoplankton figures to support a direct relation with the scattering of light, determined with his new scattering meter. The diatoms were centrifuged, identified, and counted by H. Högland, who in later work instead of centrifuging allowed the cells to settle. Atkins \& Poole (1933) measured the extinction coefficient in spring just when phosphate consumption indicated that a great increase in the phytoplankton had already occurred. They found it low. Evidence has since been obtained which shows 
that such clearing of the water may be due to the sinking of the diatoms and to their consumption by animals. Further, the extinction coefficient is not largely affected by scattering when it is determined by measuring the illumination falling on horizontal plates, since light scattered out of the direct beam is compensated for by light scattered in.

There is no doubt that water masses may be characterized by the extinction coefficient. This has been shown by Jerlov \& Koczy (I947) and in much detail by Jerlov (I950, I95I) also by Krey (I952). Joseph (I950) has recorded changes in extinction while the ship steamed ahead. When, however, we are dealing with a stable water mass, or one the movements of which are within an area experiencing closely similar meteorological conditions, it is then profitable to study the changes in visual range as a rapid and simple indication of changes in phytoplankton. Riley (I94I) recorded this inverse relation, a rich plankton with Secchi disc 5.5-8.5 m, even down to 3.5 in April, and a lesser amount of plankton with $\mathrm{I} 2.5$ to $\mathrm{I} 9 \mathrm{~m}$. Riley followed the changes in the chlorophyll content of the matter filtered out, as has since been done by Gessner (I944) and others.

Fig. 2 shows the visual range in metres of the $20 \mathrm{~cm}$ Secchi disc at Station E I from September I95I to November 1953, the scale being on the right-hand ordinate. On the left is the scale for chlorophyll in milligrams per $\mathrm{m}^{2}$ in the surface to $20 \mathrm{~m}$ water column, $\mathrm{I} \mathrm{m}^{2}$ in area. Very strikingly the minimum visual range, $7.5 \mathrm{~m}$, was observed on II May 1953, when the chlorophyll from 0 to $20 \mathrm{~m}$ was almost at a maximum. On I6 August $1948,7.5 \mathrm{~m}$ was also recorded, but nothing is known of the chlorophyll or plankton for that day. But on 8 June 1953 the disc was seen to $22 \mathrm{~m}$ with the minimum amount of chlorophyll. The clearest water for the years 1948 onwards was observed on I9 June I952, with $23 \mathrm{~m}$ and only $37 \mathrm{mg}$ chlorophyll in the column. But by 22 September 1952 the chlorophyll had risen to $23 \mathrm{I} \mathrm{mg}$ as a result of the growth consequent upon vertical mixing which brought up phosphate, etc. The visual range had also risen, after having been down to II $\mathrm{m}$ in August, up to $\mathrm{I} 8 \mathrm{~m}$ in September; it would not have been so high but for the recent mixing with the deeper water poor in plankton. One cannot therefore say that an increase in the visual range necessarily indicates a decrease in phytoplankton.

There was always watchfulness to see whether such changes in visual range were due to clearer oceanic water having moved into or across the English Channel. But salinity determinations gave no evidence in favour of such movements at the dates concerned. Thus on 27 April and II May with high chlorophyll the $0-20 \mathrm{~m}$ salinity averaged 35.18 and 35.16 , whereas with minimum chlorophyll on 8 June the salinity averaged 35.13 at Station E I. The very slight decrease in salinity is accounted for by dilution with river water.

Again, between 5 and 20 October 1953, the whole isothermal water column at $\mathrm{E}$ I rose $0.50^{\circ} \mathrm{C}$. This might be taken to show that warmer water had come 


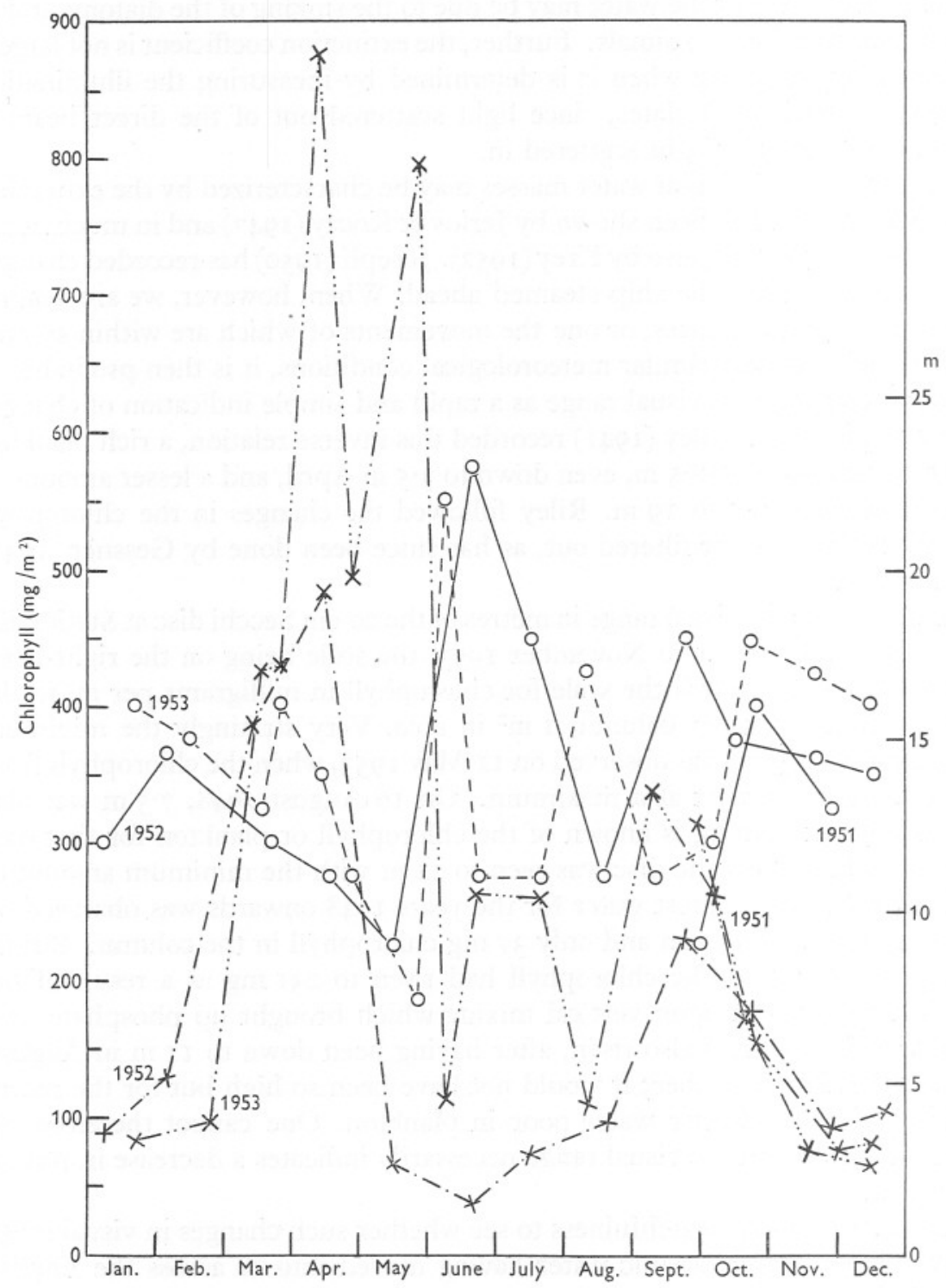

Fig. 2. The left-hand ordinates show chlorophyll in milligrams, the content of a column of sea water at Station E I, of area $\mathrm{I} \mathrm{m}^{2}$ and depth $20 \mathrm{~m}$. The right-hand ordinates show the visual range of the $20 \mathrm{~cm}$ diameter Secchi disc. The abscissae show months. Chlorophyll is shown by a dash and two dots for I951 September to November; for 1952 by a dash and dot line; for 1953 by a dash and three dots. Visual ranges for 195 I September to November and for 1952 are shown by full lines, for 1953 by a broken line. 
up from the south. But the occurrence was probably due to a local warming during a very sunny period, $4.78 \mathrm{~h}$ sunshine daily average, as against 2.62 for the rest of October, the monthly averages for which have been (I950) $3.47 \mathrm{~h}$, (I95I) $4.38 \mathrm{~h}$, (I952) $3.19 \mathrm{~h}$, and (I953) $3.73 \mathrm{~h}$. Furthermore, the salinity at EI was, as average $0-20 \mathrm{~m}, 35.22 \%$ on 5 October and $35.21 \%$ on 20 October with identical surface values nearer shore at Station $\mathrm{L}_{4}$ (about 5 miles from Plymouth Sound). The effect of the Sound water had pushed out farther during the summer months, but its influence upon visual range appears to have been negligible as compared with that of phytoplankton increase or decrease.

A low visual range in winter, or in exceptionally stormy weather, may be merely an indication of the stirring up of bottom deposits. Judging by the filter-disc photographs and albedo determinations, turbidity arising from the bottom must be very rare at $\mathrm{E}_{\mathrm{I}}$, in weather when it is possible for the ship to work, save possibly during the isothermal mixing period. The bottom gave a relatively dark disc on 25 March I953, due to a rich phytoplankton, but did so on 20 July because the whole column was remarkably poor in suspended matter. Marshall \& Orr long ago (I928) reported that 'during the spring months it was not uncommon in shallow water to find more plankton near the bottom than anywhere else'. They also found that during the spring outburst the phytoplankton caused such a great reduction in submarine illumination that the compensation point (or depth) was at times raised to $5 \mathrm{~m}$ or less.

We are indebted to the captains, crews and naturalists in charge of the Research Vessels Sabella and Sula for the samples, temperatures and visual range observations, also to $\mathrm{Mr} \mathrm{F}$. A. J. Armstrong for filtering some of the samples, and to Dr H. H. Poole for valuable criticisms.

\section{SUMMARY}

When sea water of Station E I is filtered through membranes of average pore diameter about I $\mu$ the suspended matter, organic and inorganic, is usually seen to be greatest at the surface, occasionally at $25 \mathrm{~m}$ or other intermediate depths, and but rarely at the bottom, $70 \mathrm{~m}$. High amounts, elsewhere than at the surface, are due to phytoplankton. The suspended matter, after ignition, was $\mathrm{I} \cdot 6$ parts per million at the surface in a June sample, with $\mathrm{I} \cdot \mathrm{O}$ at 5-10 $\mathrm{m}$ and 0.4 p.p.m. below. Values given previously, based on surface samples only, are too high.

Microscopic examination of the discs, carried out by Dr A. G. Lowndes, shows that the ground mass is fine clay. Fibres from woods, ropes and twines were also seen and black carbonaceous specks volatilized by heating the slide. There were also diatoms, copepods, sponge spicules, a small amount of kaolinite, specks of iron oxide, quartz grains, cordierite, micaceous matter probably sericite, tourmaline and broken grains of felspar (orthoclase). 
Fragments of shell were common. Most of the grains were under $40 \mu$ in diameter.

Comparison between successive months can be made from photographs of the discs, but more accurately by determining the relative albedo with a photoelectric cell. The lowest albedo was $25 \%$, for 2 I January. The lowest column values of the albedo were for 5 October, when the water had just become isothermal, and the $5 \mathrm{~m}$ interval mean, with appropriate interpolation, gave relative albedo 54, with similarly 64 for January and 8I for August. But the effects for mineral matter and plankton are not truly additive.

There is an inverse relation between the amount of phytoplankton determined by spectrophotometric analysis of chlorophyll extracts, and the visual range of the $20 \mathrm{~cm}$ Secchi disc, though admixture of suspended inorganic matter may at times disturb the relation. Very clear water is always poor in phytoplankton. Water unusually turbid for the locality is probably rich. The conclusions are based on a study of Station E I for two years and a quarter.

\section{REFERENCES}

Armstrong, F. A. J. \& Atrins, W. R. G., I950. The suspended matter of sea water. F. Mar. biol. Ass. U.K., Vol. 29, pp. 139-43.

Atkins, W. R. G., I922. The respirable organic matter of sea water. F. Mar. biol. Ass. U.K., Vol. I2, pp. 772-80.

Atrins, W. R. G. \& Jenkins, Pamela G., I953. Seasonal changes in the phytoplankton during the year $195 \mathrm{I}-52$ as indicated by spectrophotometric chlorophyll estimations. F. Mar. biol. Ass. U.K., Vol. 31, pp. 495-508.

Atrins, W. R. G. \& Poole, H. H., I933. The photo-electric measurement of the penetration of light of various wavelengths into the sea and the physiological bearing of the results. Phil. Trans. B, Vol. 222, pp. 129-64.

- I952. An experimental study of the scattering of light by natural waters. Proc. roy. Soc. B, Vol. I40, pp. $32 \mathrm{I}-38$.

Gessner, F., I944. Der Chlorophyllgehalt der Seen als Ausdruck ihrer Productivität. Arch. Hydrobiol, Bd. 40, pp. 687-732.

Jerlov, N. G., I950. Optische Bestimmungen von Schwebestoffen im Meere. Naturwissenschaften, Bd. 37, H. 15, p. 359.

- I95I. Optical studies of ocean water. Rep. Swedish Deep-Sea Exped., Vol. 3 (Phys. \& Chem.), No. I, 69 pp.

- I953. Particle distribution in the ocean. Rep. Swedish Deep-Sea Exped., Vol. 3 (Phys. \& Chem.), No. 3 .

JerLov, N. G. \& Koczy, F., I947. Records of transparency in Gullmar fjord. f. Cons. Int. Explor. Mer, Vol. 15, p. 39.

JosEPH, J., I950. Durchsichtigskeitsregistrierungen als ozeanographische Untersuchungsmethode. Dtsch. hydrogr. Z., Bd. 3, H. I/2, pp. 70-7.

KREY, J., I952. Die Characterisierung von Wasserkörper durch optische Messungen. Arch. Hydrobiol., Bd. 46, pp. I-I4.

Marshall, Sheina M., I933. The production of microplankton in the Great Barrier Reef region. Sci. Rep. Gr. Barrier Reef Exped., Vol. 2, No. 5, pp. II I-57.

MARShall, S. M. \& ORR, A. P., I928. The photosynthesis of diatom cultures in the sea. F. Mar. biol. Ass. U.K., Vol. I5, pp. 321-60. 
Pettersson, H., I934a. A transparency meter for sea water. Göteborgs VetenskSamh. Handl., Ser. 5, Bd. 3, No. 8.

- I $934 b$. Scattering and extinction of light in sea water. Göteborgs VetenskSamh. Handl., Ser. 5, Bd. 4, No. 4.

RILey, G. A., I94I. Plankton studies 4. Georges Bank. Bull. Bingham oceanogr. Coll., Vol. 7, Art. 4, 73 pp.

Russell, F. S. \& Colman, J. S., I934. Sci. Rep. Gr. Barrier Reef Exped., Vol. 2, No. 6, pp. 159-75. 